\title{
Risk Assessment Analysis of Accelerated Gully Erosion in Ikpoba Okha Local Government Area of Edo State, Nigeria
}

\author{
Aderemi Adediji ${ }^{1} \&$ Iyamu Felix ${ }^{1}$ \\ ${ }^{1}$ Department of Geography, Obafemi Awolowo University, Ile-Ife, Nigeria \\ Correspondence: Aderemi Adediji, Department of Geography, Obafemi Awolowo University, Ile-Ife, Nigeria. \\ E-mail: remiadediji2003@yahoo.co.uk
}

Received: October 30, 2012 Accepted: December 10, 2012 Online Published: December 15, 2012

doi:10.5539/enrr.v3n1p68 URL: http://dx.doi.org/10.5539/enrr.v3n1p68

\begin{abstract}
The problem of accelerated erosion has been on in Ikpoba-Okha Local Government Area (LGA) in particular and Nigeria at large for some decades now and all past attempts at solving the problem have proved ineffective and thus constituting risk to the people living around the gullies in the area. Therefore, this study aimed at determining sediment loss from the gully sites, the vulnerable areas and threat posed by impact of gullies in the study LGA.

Oregbeni Housing Estate and Ede School gully erosion sites in the Ikpoba-Okha LGA were purposively selected for this study. Primary data were collected using GPS receiver.These include the geographic coordinates and elevation of the study gullies catchments which were integrated with the secondary data obtained from satellite image, topographic, geologic, road and lay out maps of the area using Arc GIS 9.3 software. The results of the satellite image classification analysis showed that accelerated gully erosion accounted for $2 \%\left(100466.57 \mathrm{~m}^{2}\right)$ of the total areal extent of the study LGA $\left(5189010.57 \mathrm{~m}^{2}\right)$. Of this $2 \%$, Queen Ede School gully accounted for $96957.13 \mathrm{~m}^{2}$. The total estimated sediment loss from Queen Ede School and Oregbeni Housing Estate gullies were 359,173.22 and 48,212.62 tonnes, respectively. These indicated severe land degradation in the study area.
\end{abstract}

Keywords: gully erosion, risk assessment, vulnerability, Ikpoba-Okha Local Government Area (LGA)

\section{Introduction}

Soil erosion is a geomorphic process whereby the surface layer of weathered rock is loosened and carried away by wind, running water, wave, ice and a lower horizon in the soil/ rock is exposed (Ofomata, 1988). Ordinarily, soil erosion when balanced with soil formation is said to be normal only when it occurs as a natural process. However, erosion becomes serious only when it is accelerated. The term "accelerated erosion" is often used when the removal of soil is far faster than its replacement or the natural way by which the soil is formed. Thus, accelerated erosion is defined as the displacement and removal of soil from a land surface such that the removal process far exceeds its replacement by pedological process (Strahler, 1975). According to Strahler (1975), the area of the world estimated to be suffering from some form of land degradation stands at just below 2 billion hectares. In this regard, fluvial erosion affects about $56 \%$ of the degraded land area, and thereby making it a major factor contributing to the process of land degradation (Swai, 2001). Also, Ofomota (1978) observed that out of $75,488 \mathrm{~km}^{2}$ land of southern eastern Nigeria, accelerated soil erosion has affected $53,028 \mathrm{~km}^{2}$ or $71.25 \%$ of the total land area. Soil erosion has been recognized not only in the rural area but also in urban environment for several years in Nigeria and in many other parts of the world (e.g. Akintola, 1978; Okoye, 1988; Jeje, 1988, 2005; Enabor \& Sagua, 1983; Adediji et al., 2009). However, this study presents a method by which soil erosion can be assessed in the field hierarchically and its risk modeled using field data, remote sensing (RS) and geographic information system (GIS). An environment is considered to be at risk when any of the mitigating factors of erosion in the terrain (surface cover, slope, land management practice and soil erodibility) favour the occurrence of soil erosion. The risk factors change according to the prevailing conditions whether man-made or natural conditions. Therefore, the main thrust of this study is on observing feature of soil erosion and how they can be used in assessment and modeling of erosion risk. Hence, this study will attempt to assess the risk of accelerated soil erosion in Ikpoba-Okha LGA, Edo State, Nigeria. 


\section{Study Area}

Aduwawa, Oregbeni and Ogbeson communities within Ikpoba-Okha Local Government Area, Edo State, Nigeria constitute the study area. The selected communities are prone to serious erosion problems.

The Ikpoba-Okha LGA was carved out of the defunct Oredo Local Government Council of Edo State. It lies between latitudes $6^{\circ} 15^{\prime} \mathrm{N}$ and $6^{\circ} 25^{\prime} \mathrm{N}$ and Longitudes $5^{\circ} 30^{\prime} \mathrm{E}$ and $5^{\circ} 50^{\prime} \mathrm{E}$ of the Greenwich Meridian (see Figure $1)$.

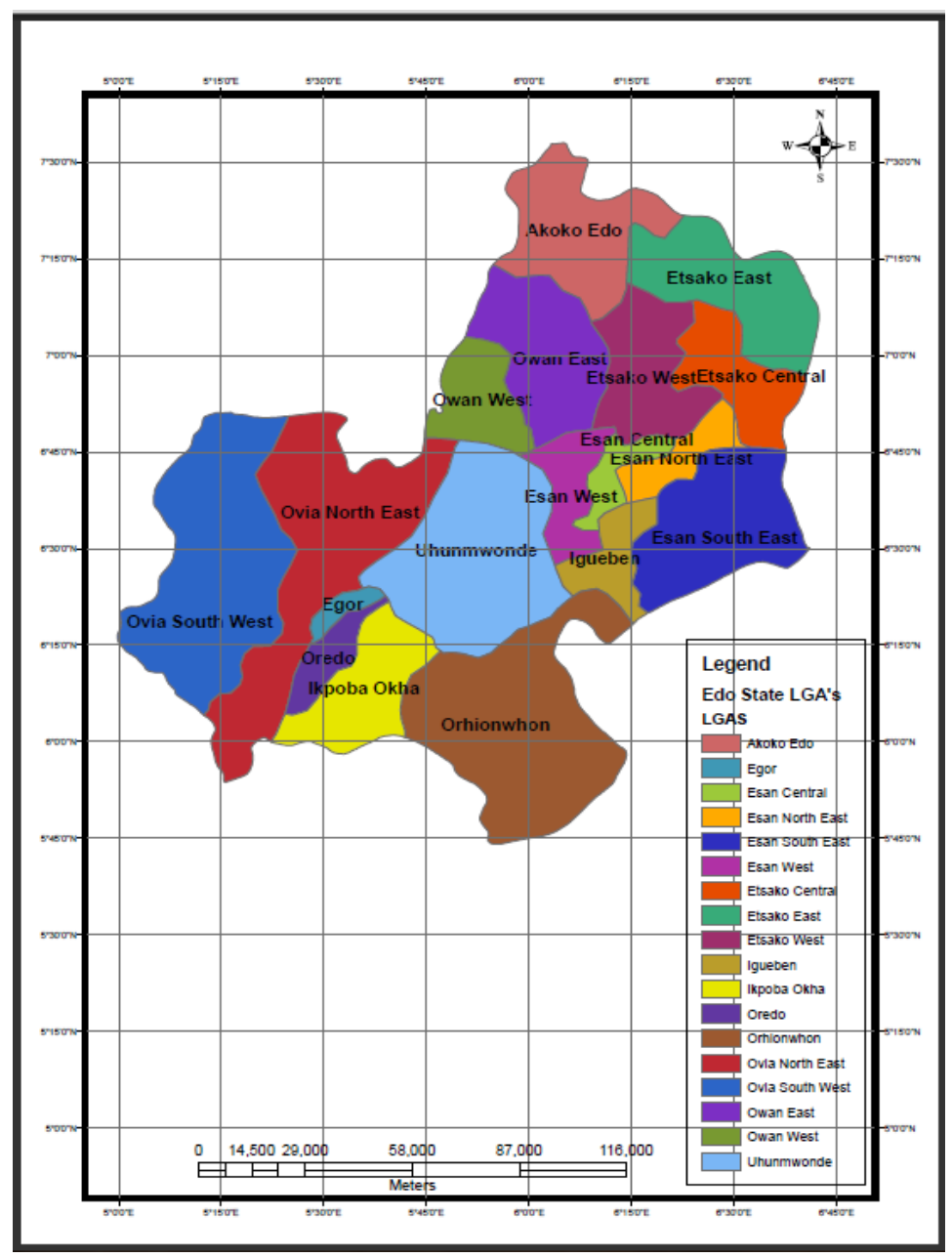

Figure 1. Map of Edo State LGAs and the study area (Source: Digitized from Edo State Political Map, Lands and Surveys Department)

The area experienced tropical rainforest climate designated as Af by Koppen. Temperatures in the area are always high with a mean maximum of $25^{\circ} \mathrm{C}$ in August (Nigeria meteorological office, Benin City). The area experiences rainy season from March to November and dry season for the rest of the year, with the mean annual rainfall ranging from $1200 \mathrm{~mm}$ to $2200 \mathrm{~mm}$. More than $80 \%$ of the erosive rainfall is concentrated between the months of April and September (Ayoade, 1975). The rain falls on the exposed land and the increase impervious surfaces have combined to increase surface runoff and subsequently produce gullies in the area. The area is also characterized by few scattered rainforests, wooded shrub lands and farmlands. The area is underlain by sedentary rock of the Pleistocene age often referred to as the Benin formations. This formation is dominantly arenaceous comprising of soft, poorly sorted, unconsolidated, cross bedded, occasionally pebbly yellow and white sands. The soils developed on Benin formation around the city belong to the Kulfo series (Moss, 1957). The soils are reddish brown clayey sand to depths of more than $10 \mathrm{~m}$ and have low silt content while clay fraction increases with depth (Jeje, 2005). The soils of the area are shown in Figure 2. Common to all the earth material at different locations in the area is that under agricultural land use, they are porous and highly permeable and where covered 
by tree crops no matter how high the rainfall is, little or no surface runoff is generated.

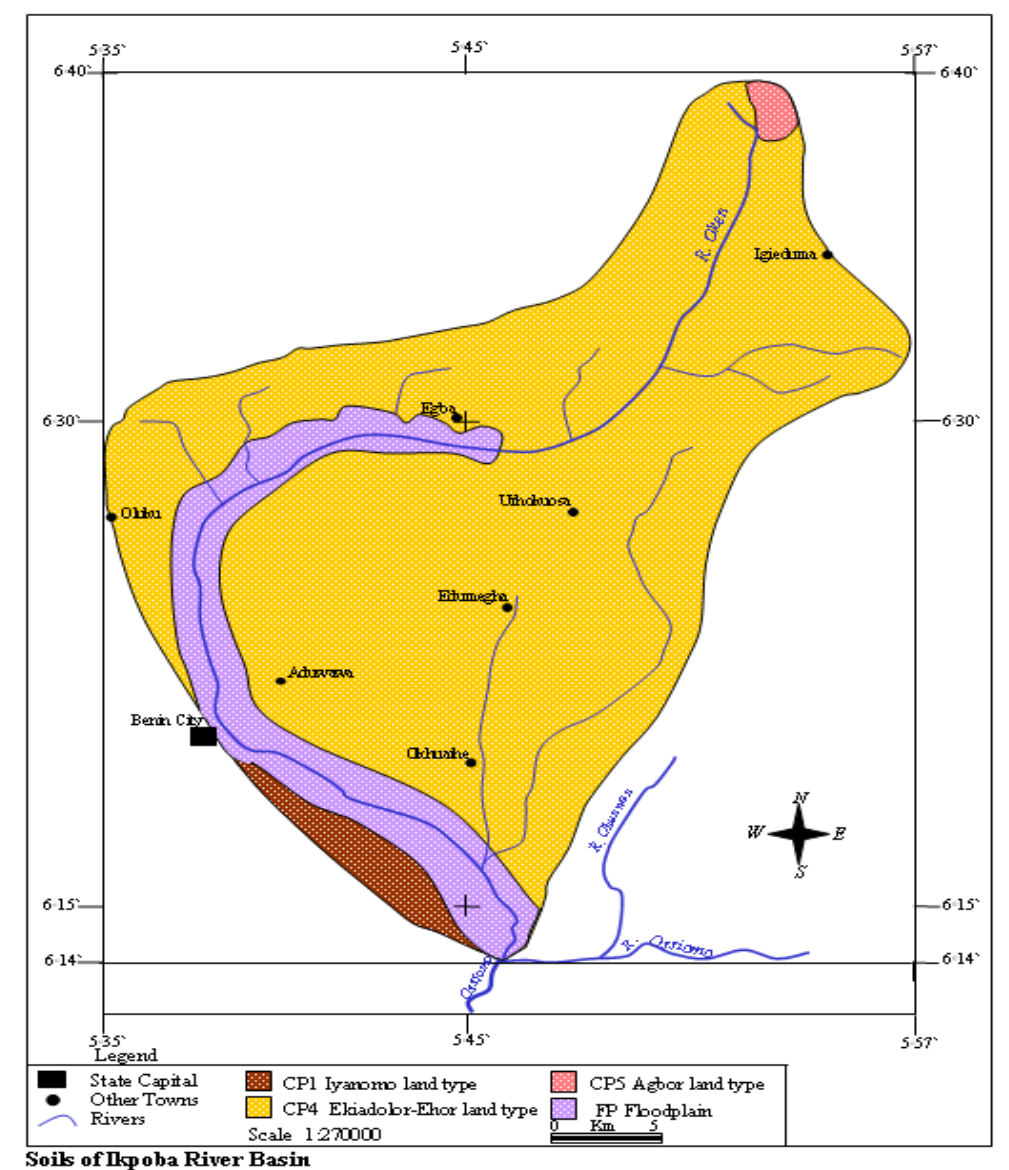

Figure 2. Showing the soils of the Ikpoba River Basin (Source: Akujeze, 2004)

However, with severe compaction under urban land use, the top soils acquired higher values of bulk density, and thus becoming relatively impermeable so that whenever its rains, runoffs are generated which subsequently produced gullies in the area.

\section{Materials and Methods}

Oregbeni Housing Estate and Queen Ede School gullies in the Ikpoba-Okha Local Government Area (LGA) of Edo State, Nigeria were purposively selected for this study. This is because of their size and proximity to human settlement in the area. Data on the length, width and depth of each gully channel was determined using leveling instrument, abney level, measuring tape and surveyor's pegs. The measurement of length, width and depth of the study gullies were taken at regular interval of 10 meters. All points intervals which include both the upper and basal parts of gullies catchments were measured using Germin 72 Global Positioning System (GPS). The GPS readings, the coordinates and the elevation or spot heights were determined and used to construct the Digital Elevation Model (DEM) of the study gullies using Arc GIS 9.3.

The cross-sectional area of each of the study gullies was determined using a formula adopted by Ofomata (2000) in southeastern Nigeria. The formula is given as:

$$
\mathrm{A}=\mathrm{wd}
$$

Where $\mathrm{A}=$ Cross-sectional area $\left(\mathrm{m}^{2}\right)$

$\mathrm{W}=$ mean width of the gully

$\mathrm{d}=$ mean depth of the gully 
The value of the cross-sectional area obtained was used to estimate the volume of soil removed by gully erosion from each of the study gully catchments. Therefore, the prismoidal formula was used in this study (see Bannister and Raymond, 1983). The amount of soil loss from the gully site was estimated by multiplying volume with the soil bulk density (see Jeje, 2005; Adediji et al., 2009). The bulk density was determined from the core samples taken from the floor of each of the study gullies using a McCauley corer of approximately $5.5 \mathrm{~cm}$ in diameter and $4 \mathrm{~cm}$ in height.

Also, medium resolution satellite imagery of the study area was acquired from Google Earth specifically for mapping of streets, building footprints and land cover. The flow chart and vector data model for this study method are shown in Figure 3 and Figure 4, respectively.

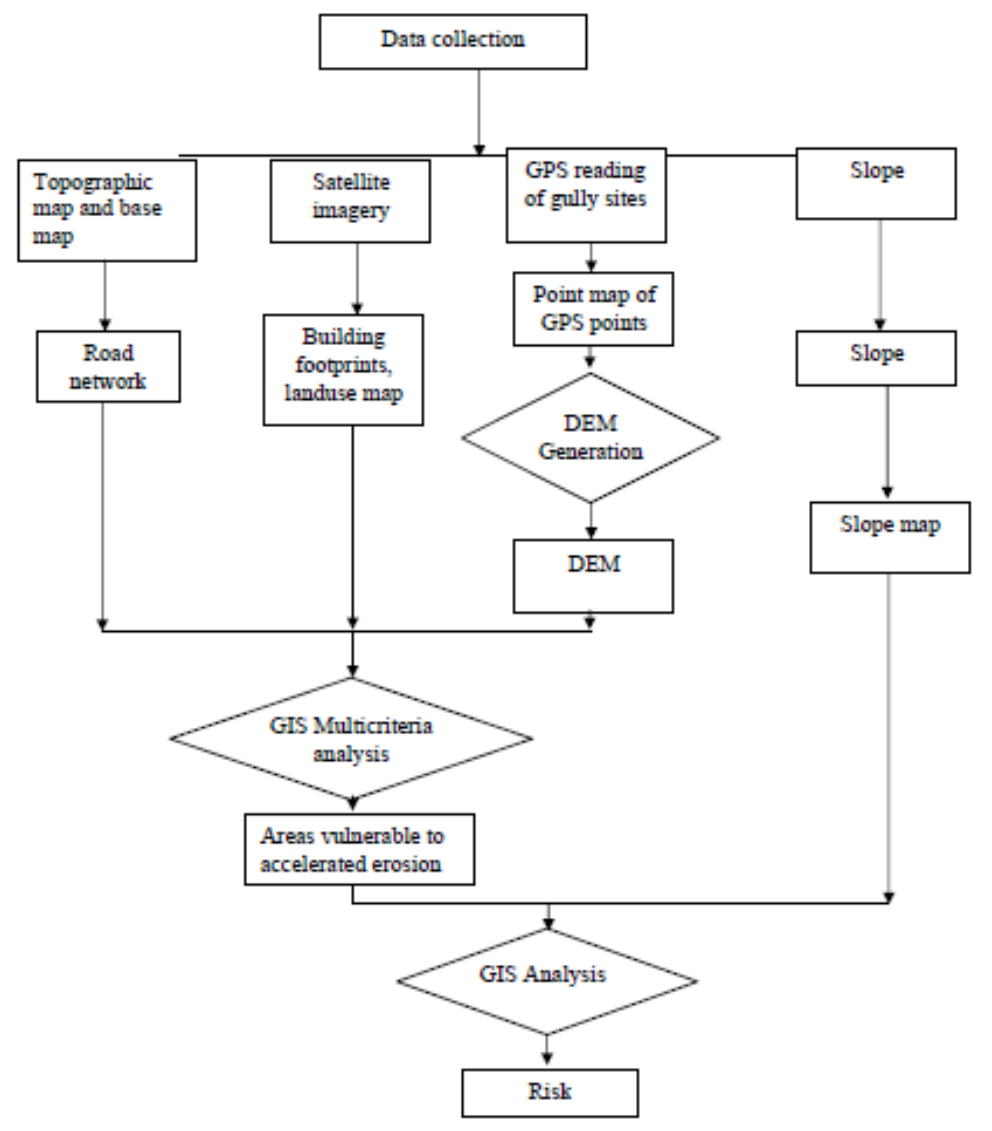

Figure 3. Cartographic modeling of the research methods

Vulnerability assessment is an approach for identifying and determining areas susceptible or vulnerable to natural hazards and man-made or anthropogenic hazards. This involves the assessment of the biophysical and socio economics parameters, erosion area identification and critical factor analysis. Vulnerable areas to accelerated gully erosion in the study area was determined using the Soil and Water Assessment Tool (SWAT), a physically based distributed hydrological model and GIS based on a decision support system that uses multicriteria evaluation (MCE). Specifically, the SWAT model was used to estimate the sediment yield within the basin and identify the sediment contributing areas to the Ikpoba River in the study area. In this regard, four factors or criteria were selected for the modeling. These are slope factor, land use/cover, soil and river. The weighted overlay tool in the ArcGIS 9.3 software was used for vulnerability modeling of the study area. In this study, six scenarios were adopted depending upon the priority given to the factors. For instance, in the first scenario, slope factor was given the highest priority followed by land cover, soil and river. It is also possible to determine the degree of consistency that has been used in developing the ratings of erosion. The consistency ratio (CR) indicates the probability that the matrix ratings are randomly generated. After the whole process is completed the final MCE erosion potential area map was produced. The map shows the degree of erosion sensitivity of each area. The details on the factors selected for vulnerability assessment is documented elsewhere 
(see Iyamu, 2012).

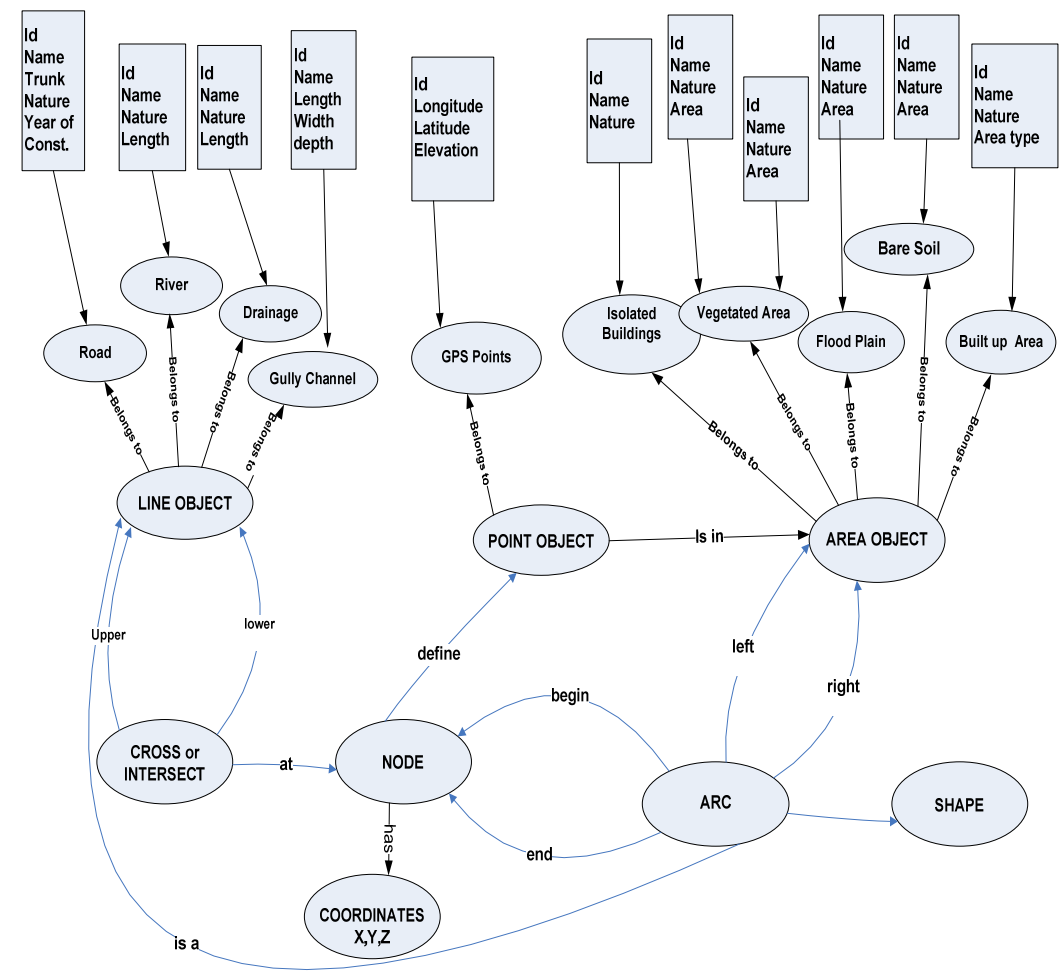

Figure 4. Vector data model

\section{Results and Discussion}

As evident from Table 1, the total eroded area in the Okpba-Okha LGA is estimated at $100466.57 \mathrm{~m}^{2}$. Of this amount, Queen Ede school gully accounted for about 95\% $\left(96,957.13 \mathrm{~m}^{2}\right)$ of the total eroded area while the surface area of Oregbeni Housing Estate gully is about $3509.44 \mathrm{~m}^{2}$. Also, the area extent of each of the land uses identified from the image of the study area is shown in Table 2 and Figure 5. As shown in Table 2, built-up area and eroded area accounted for $66 \%$ and $2 \%$ of the study area, respectively. Areal extent covered by the vegetated area and flood plain are $942410.91 \mathrm{~m}^{2}$ and 514,412.04 $\mathrm{m}^{2}$, respectively (see Table 2).

Table 1. Erosion surface area

\begin{tabular}{|c|c|c|c|c|c|}
\hline $\mathrm{S} / \mathrm{No}$ & LAND USE CLASS & LOCATION & Perimeter $(\mathrm{m})$ & Area $\left(\mathrm{m}^{2}\right)$ & $\%$ \\
\hline 1 & Erosion area & Queen Ede School & 3500.06 & 96957.13 & 96.5 \\
\hline \multirow[t]{2}{*}{2} & Erosion area & Oregbeni Housing Estate & 990.34 & 3509.44 & 3.5 \\
\hline & TOTAL & & 4490.40 & 100466.57 & 100.0 \\
\hline
\end{tabular}

Table 2. Areal extent covered by the various land uses

\begin{tabular}{ccccc}
\hline S/No & Landuse class & Area $(\mathrm{Sqm})$ & \% Coverage & Perimeter $(\mathrm{m})$ \\
\hline 1 & Built up area & 3441154.46 & 66 & 109674.61 \\
2 & Bare soil & 155829.65 & 3 & 14773.94 \\
3 & Vegetated area & 942410.91 & 18 & 58986.13 \\
4 & Erosion area & 100466.57 & 2 & 4490.39 \\
5 & Flood plain & 514412.04 & 10 & 6294.62 \\
6 & Water Body & 34736.94 & 1 & 5733.44 \\
& TOTAL & 5189010.57 & 100 & 199953.13 \\
\hline
\end{tabular}




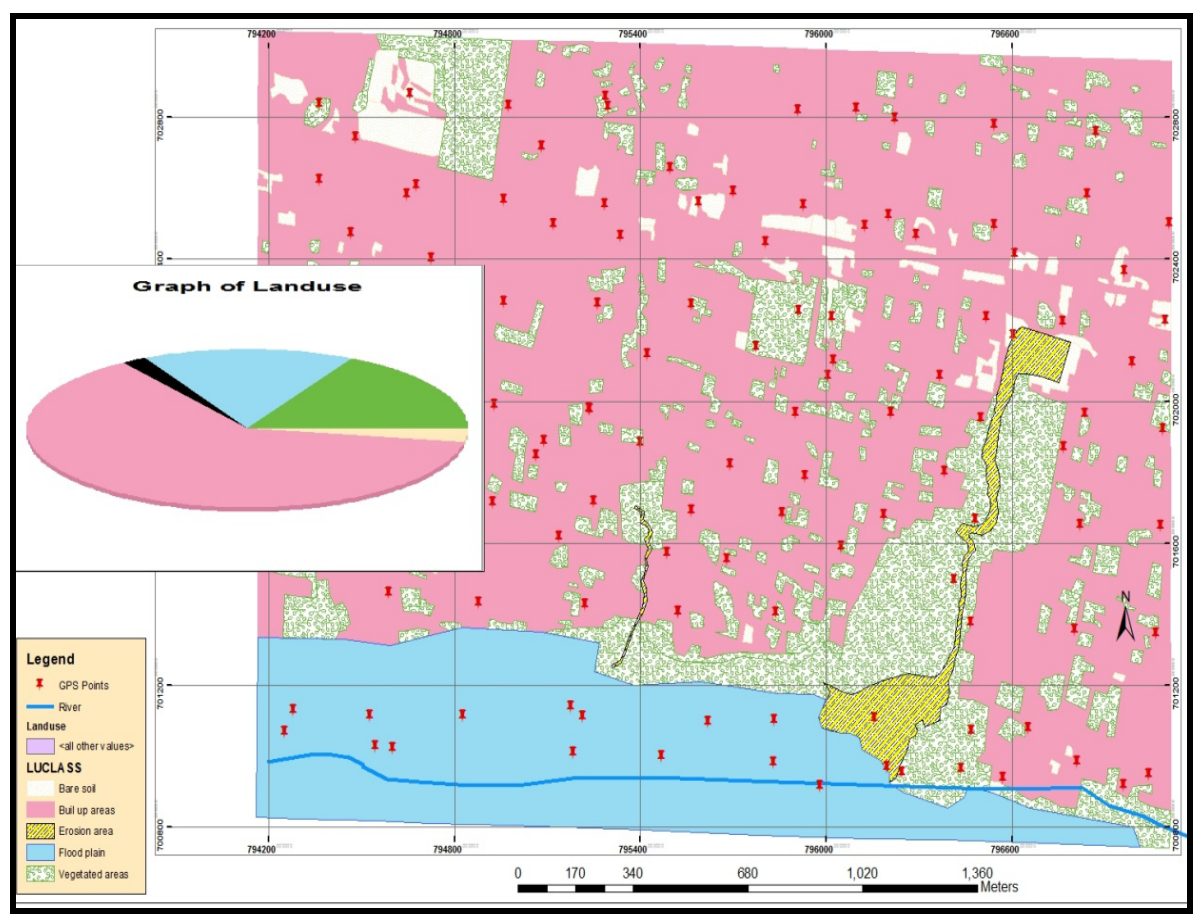

Figure 5. Map of the study area showing land use classification

Also, as displayed in the Table 3, large tonnes of sediment were lost to erosion. This is an evidence of severe land degradation in the area. For instance, the total volume of soil loss and weight of sediment loss at Queen Ede school gully was highest with value of $292,010.75 \mathrm{~m}^{3}$ and $359,173.72$ tonnes, respectively. The values obtained in this study was by far higher than volume of soil loss $\left(5,772.75 \mathrm{~mm}^{3}\right)$ obtained from similar gully in Ogiso area of Benin City by Esere (2006). Also, the estimated soil loss from the study gullies though higher but however comparable to the findings by Adediji et al. (2009) from accelerated gullies at Irele LGA of Ondo State, Nigeria and by extension Ofomata's (2000) findings in southeastern Nigeria. The volume of soil loss at Queen Ede School $\left(292,010.75 \mathrm{~m}^{3}\right)$ and Oregbeni Housing Estate $(39,197.25)^{3}$ is also higher than the $6,900 \mathrm{~m}^{3}$ of material eroded from the 7-8 ha gully system in the North Island East Region, New Zealand by Harley et al. (2003).

Table 3. Total volume of soil $\left(\mathrm{m}^{3}\right)$ and sediment loss (Tonnes)

\begin{tabular}{cccccccc}
\hline S/No & Gully site & $\begin{array}{c}\text { Total length } \\
(\mathrm{m})\end{array}$ & $\begin{array}{c}\text { Mean width } \\
(\mathrm{m})\end{array}$ & $\begin{array}{c}\text { Mean } \\
\text { depth } \\
(\mathrm{m})\end{array}$ & $\begin{array}{c}\text { Total } \\
\text { CSA } \\
\left(\mathrm{m}^{2}\right)\end{array}$ & $\begin{array}{c}\text { Total } \\
\text { volume } \\
\left(\mathrm{m}^{3}\right)\end{array}$ & $\begin{array}{c}\text { Sediment loss } \\
\text { (Tonnes) }\end{array}$ \\
\hline 1 & Queen Ede School & 800 & 27.78 & 12.15 & $22,227.5$ & $292,010.75$ & $359,173.22$ \\
2 & Oregbeni Housing Estate & 330 & 16.55 & 6.12 & $5,462.5$ & $39,197.25$ & $48,212.62$ \\
\hline
\end{tabular}

Where CSA $=$ Cross Sectional Area of Gully.

As evident from the Digital Elevation Model (see Figures 6a and 6b), the study gullies are situated on the steepest areas of the terrain. This coupled with high rainfall amount and intensity in the area may have accounted for the huge volume of soil loss obtained from the study gullies. In this regard, the slope factor especially the greater slope angle may not be unconnected to the huge estimated soil loss obtained from the study gullies in the Ikpoba-Okha LGA in Benin City, Edo State, Nigeria. 


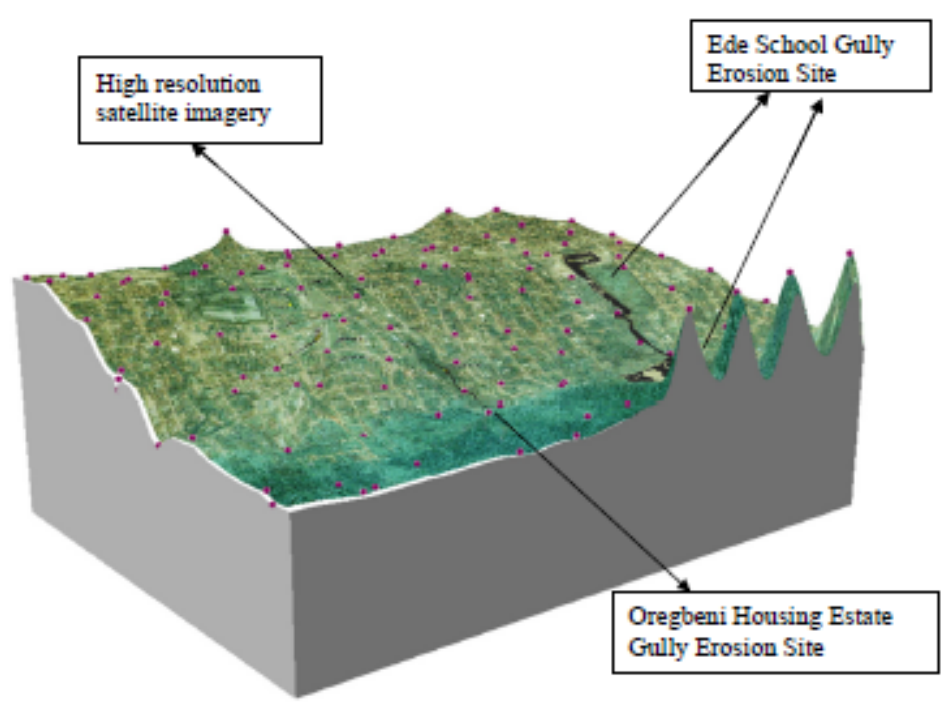

Figure 6a. Digital elevation model of the study area, Oregbeni housing estate and Ede school gully lying in one of the steepest areas of the Terrain

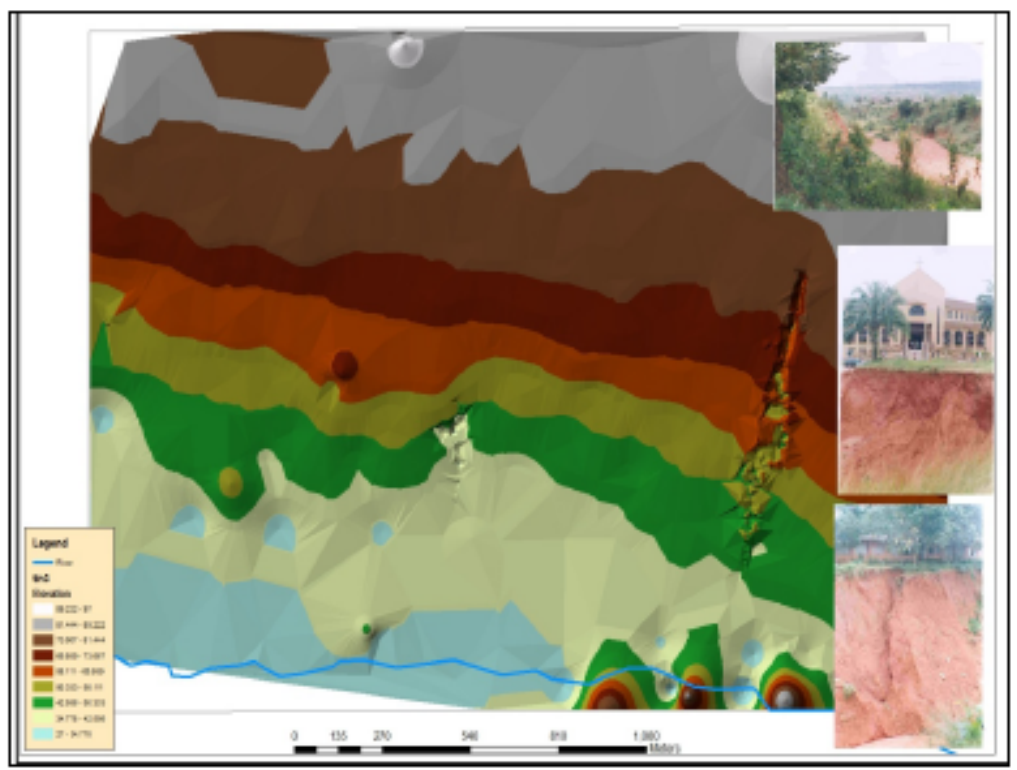

Figure $6 \mathrm{~b}$. Digital elevation model on TIN Surface and extent of degradation in the area by gully

With respect to vulnerability analysis, Figures 7 and 8 showed various scenarios of buildings and roads that are threatened by erosion. Specifically, there are 15 buildings and 4 road networks under very severe threat from the gully erosion at Queen Ede School, off Benin-Asaba Road, Benin City. As evident from figure 7, the polygon in the red signifies areas that are under severe threat to gully erosion. This implies that all the buildings inside the polygon are under severe threat of gully. In this regard, the number of people in each building can be estimated in order to arrive at the total population under severe threat of accelerated erosion. Also, as displayed in figure 8, the area most vulnerable is the built-up part of the study area where there is little or no vegetal cover. This can subsequently increase surface runoff and erosion. Areas vulnerable to gully erosion are also located on the steeper slopes and unstable geology. This may be enhanced further by high rainfall which causes the saturation of soils as rightly observed in the study area. 


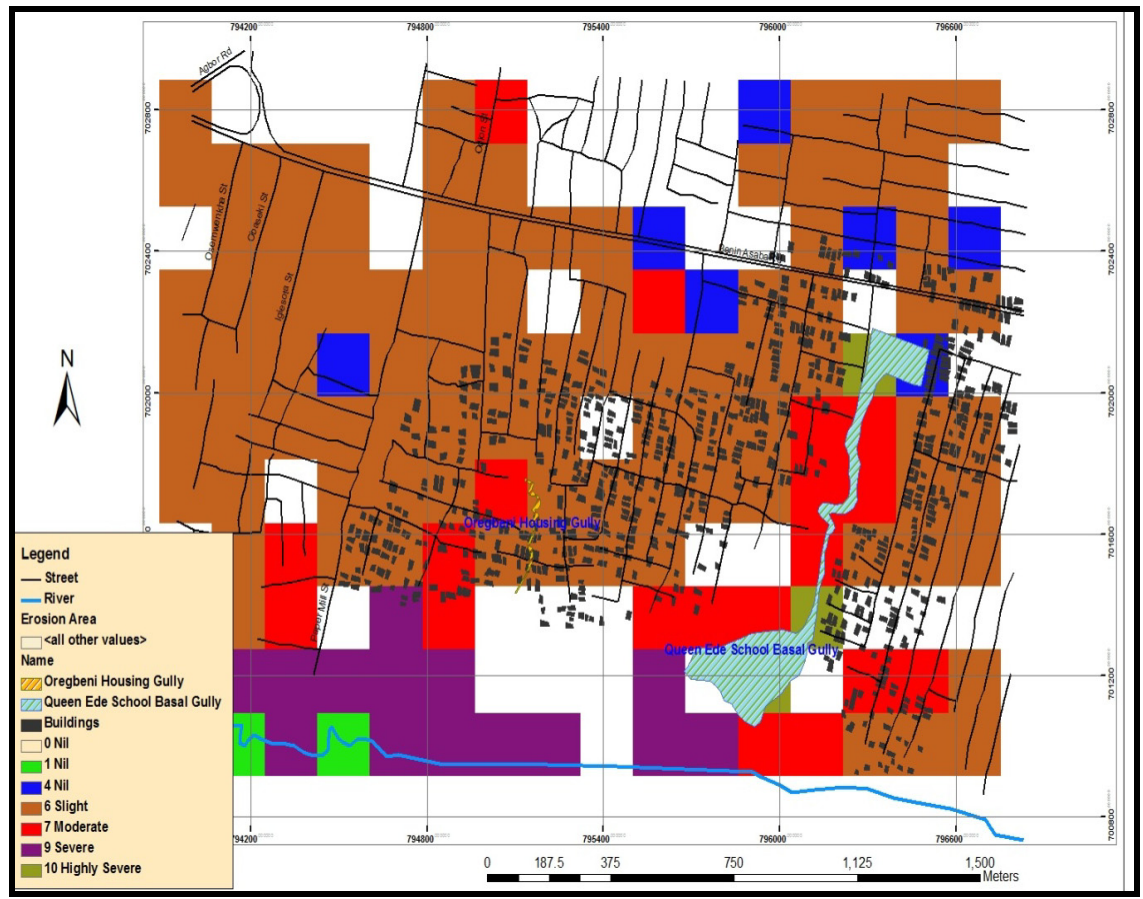

Figure 7. Vulnerable areas to erosion

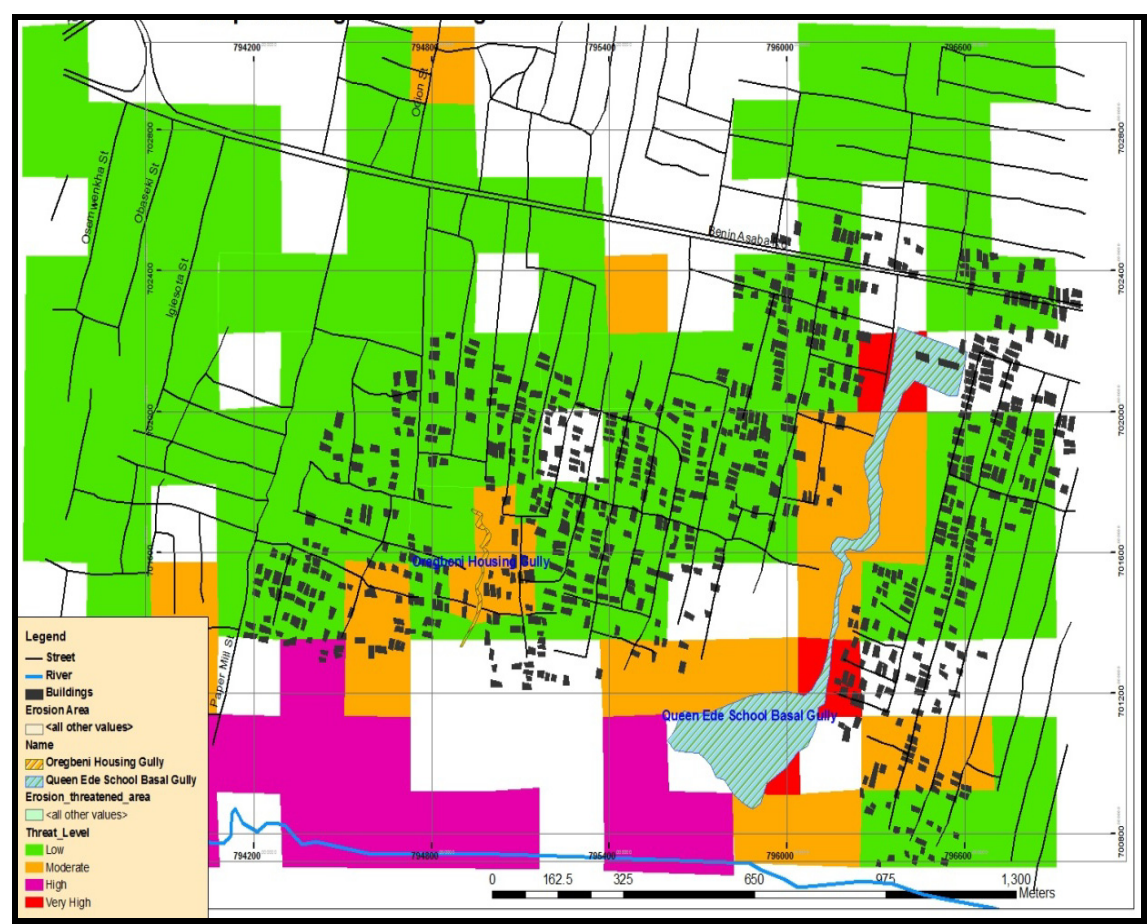

Figure 8. Map showing building and roads under different threat levels to erosion

\section{Conclusion}

This study investigated two gullies in Ikpoba-Okha LGA in Benin City, Edo State, Nigeria with a view to carry out their risk assessment analysis and identifying areas vulnerable to accelerated erosion in the study area. The results showed that the total surface area of Queen Ede School and Oregbeni Housing Estate gullies are 22, $227.50 \mathrm{~m}^{2}$ and $5,462.50 \mathrm{~m}^{2}$, respectively. Also, the satellite image analysis showed that $2 \%\left(100,466.57 \mathrm{~m}^{2}\right)$ of the total areal extent of the study area was eroded by accelerated gully erosion. The value obtained closely 
followed the size of the built-up area. Of this proportion, Queen Ede School and Oregbeni Housing Estate gullies accounted for $95 \%$ and $5 \%$ of the eroded area, respectively. Apart form the morphometric attributes measured, the total volume of soil loss at Queen Ede School and Oregbeni Housing Estate gullies are estimated at $292,010.75 \mathrm{~m}^{3}$ and $39,197.25 \mathrm{~m}^{3}$, respectively while the weight of sediment loss are also estimated at 359 , 173.72 tonnes and 48,212.62 tonnes, respectively. This is an evidence of severe soil degradation in the area.

The risk assessment analysis also showed that areas around the study gullies are highly vulnerable and also threat to lives and properties. It can be concluded that accelerated gully erosion in Oregbeni Housing and Queen Ede School has led to severe land degradation and still poses severe risk to humans and property development in the area.

\section{References}

Adediji, A., Ibitoye, M. O., \& Ekanade, O. (2009). Generation of Digital Elevation Models (DEMS) for Gullies in Irele Local Government Area of Ondo State, Nigeria. African Journal of Environmental Science and Technology, 4(3), 65-79.

Akintota, F .O. (1978). The hydrological Consequences of urbanization: A case study of Ibadan City, in Urbanization Processwaqes and Problems in Nigeria. (pp. 151-160). Ibadan: Ibadan University Press.

Bannister, A., \& Raymond, S. (1983). Surveying Longman Scientific and Technical England.

Enabor, E. E., \& Sagua, V. O. (1988). Ecological Disaster in Nigeria Soil Erosion, Introduction and Recommendations. In Sagua, V. O., Enabor, E. E., Ofomata, G. E. K., Oboge, K. O., \& Oyebande.

Esere, O. G. (2006). Economics of erosion control in a typical urban environment: A case study of Queen Ede College Road and Ogiso off Muritala Muhammed Way, Benin City. Unpublished Post Graduate Diploma Dissertation. University of Benin, Benin, Nigeria.

Harley, D. B., Trustrum, N. A., \& Ronald, C. D. (2003). Geomorphic Changes in a Complex gully system measured from sequential digital elevation models and implications for management. Earth Processes and Landforms, 18, 1043-1058.

Iyamu, F. O. (2012). Assessment and Risk Analysis of Accelerated Gully Erosion in Ikpoba-Okha Local Government Araa of Edo State, Nigeria. Unpublished M.Sc. Thesis, Department of Geography Obafemi Awolowo University, Ile-Ife, Nigeria, pp. 61-92.

Jeje, L. K. (1988). Soil Characteristics, processes and extent in the lowland rainforest areas of southwestern Nigeria. In Enabor, E. E. et al. (Eds.). Ecological Disasters: Soil Erosion published by Federal Ministry of Science and Technology, Lagos, pp. 163-189.

Jeje, L. K. (2005). Urbanization and Accelerated Erosion: Examples from southwestern Nigeria. Ngierian Journal of Environmental Management, 2, 40-53.

Moses, R. P. (1957). Report on the classification of soils over sedimentary rocks in Western Nigeria. Ministry of Agriculture and Natural Resources, Ibadan, Nigeria.

Ofomata, G. E. K. (1978). Man as a factor of soil erosion in southwestern Nigeria. Geo-Eco-Trop., 2(2), 78-89.

Ofomata, G. E. K. (1988). Soil erosion characteristics, processing and extent in the lowland rainforest area of southeastern Nigeria. In Sagua, V. O., Enabor, E. E., Ofomata, F. E. K., Ologe, K. O., \& Oyebande Lekan (Eds.). Ecological Disaster in Nigeria: Soil Erosion published by Federal Ministry of Science and Technology, Lagos, Nigeria, pp. 50-58.

Ofomata, G. E. K. (2000). Classification of soil Erosion with specific reference to Anambra State of Nigeria. Environmental Review, 3(2), 252-2555.

Okoye, T. O. (1988). Urbanization and Erosion with particular reference to Aba. In Sagua, V. O., Enabor, E. E., Ofomata, G. E. K., Ohoge, K. O., \& Oyebande, Lekan (Eds.). Ecological Disaster in Nigeria Soil Erosion Published by Federal Ministry of Science and Technology ${ }_{2}$ Lagos Nigeria, pp. 265-275.

Strahler, A. N. (1975). Physical Geography (4th ed.). New York: John Willey \& Sons Inc.

Swai, E. Y. (2001). Soil Water Erosion modeling in selected watersheds in southern Spain. International Institute for Geo-Information Science and Earth Observation (ITC), Enschede. 